\title{
Microbial communities in local and transplanted soils along a latitudinal gradient
}

Article

Accepted Version

Creative Commons: Attribution-Noncommercial-No Derivative Works 4.0

Hedenec, P., Jilkova, V., Lin, Q., Cajthaml, T., Filipova, A., Baldrian, P., Vetrovsky, T., Kristufek, V., Chronakova, A., Setala, H., Tsiafouli, M. A., Mortimer, S. R., Kukla, J. and Frouz, J. (2019) Microbial communities in local and transplanted soils along a latitudinal gradient. Catena, 173. pp. 456-464. ISSN 0341-8162 doi:

https://doi.org/10.1016/j.catena.2018.10.043 Available at https://centaur.reading.ac.uk/80784/

It is advisable to refer to the publisher's version if you intend to cite from the work. See Guidance on citing.

To link to this article DOI: http://dx.doi.org/10.1016/j.catena.2018.10.043

Publisher: Elsevier

All outputs in CentAUR are protected by Intellectual Property Rights law, including copyright law. Copyright and IPR is retained by the creators or other copyright holders. Terms and conditions for use of this material are defined in the End User Agreement. 


\section{CentAUR}

Central Archive at the University of Reading

Reading's research outputs online 
1 Microbial communities in local and transplanted soils along a latitudinal gradient

2 Petr Heděnec*a ${ }^{* a}$ eronika Jílková ${ }^{b}$, Qiang Lin ${ }^{b}$, Tomáš Cajthaml ${ }^{a, c}$, Alena Filipovác, Petr

3 Baldrian ${ }^{d}$, Tomáš Větrovskýd, Václav Krištůfek ${ }^{b}$, Alica Chroňákováb, Heikki Setäläe,

4 Maria A. Tsiafoulif, Simon R. Mortimer ${ }^{\mathrm{g}}$, Jaroslav Kukla ${ }^{\mathrm{a}}$ and Jan Frouz ${ }^{\mathrm{a}, \mathrm{b}}$

$5 \quad$ anstitute for Environmental Studies \& SoWa RI, Faculty of Science, Charles University in

6 Prague, Benátská 2, 12844 Prague 2, Czech Republic

7 bInstitute of Soil Biology \& SoWa RI, Biology Center CAS, Na Sádkách 7, 37005 České

8 Budějovice, Czech Republic

9 'cLaboratory of Environmental Biotechnology, Institute of Microbiology of the CAS, Vídeňská $10 \quad$ 1083, 14220 Prague 4, Czech Republic

11 d Laboratory of Environmental Microbiology, Institute of Microbiology of the CAS, Vídeňská 12 1083, 14220 Prague 4, Czech Republic

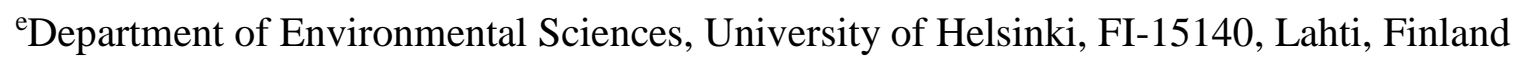

fDepartment of Ecology, School of Biology, Aristotle University, 54124 Thessaloniki, Greece

${ }^{\text {g} C e n t r e ~ f o r ~ A g r i-E n v i r o n m e n t a l ~ R e s e a r c h, ~ U n i v e r s i t y ~ o f ~ R e a d i n g, ~ R e a d i n g ~ R G 6 ~ 6 A R, ~ U n i t e d ~}$

Kingdom 


\section{ABSTRACT}

Factors shaping community structure of soil microbiota have been intensively studied; however, the pattern in community composition and structure of soil microbiota at large geographical scales and factors regulating its metabolic activity remains poorly understood. Here, we used a field transplantation experiments to investigate the effects of substrate and climatic conditions on basal soil respiration, microbial biomass $\mathrm{C}$ and diversity of soil microbiota by comparing local and transplanted soils along a latitudinal gradient. Soil samples collected in April 2008 at donor site (Sokolov, Czech Republic) in Central Europe were gammaray sterilized and transplanted to receptor sites in Europe and the USA in May and early June 2008. Soil samples were taken in June 2009 after one year of exposure and immediately prepared for laboratory analysis. Basal soil respiration in local soils increased from 22 to $42 \mathrm{mg}$ $\mathrm{CO}_{2}-\mathrm{C} \mathrm{kg}^{-1} \mathrm{~h}^{-1}$ with latitude while basal soil respiration in transplanted soils decreased with latitude from 32 to $19 \mathrm{mg} \mathrm{CO}-\mathrm{C} \mathrm{kg}^{-1} \mathrm{~h}^{-1}$. The microbial biomass $\mathrm{C}$ in both transplanted and local soils decreased with latitude. Content of fungal and bacterial phospholipid fatty acids increased nearly twice with latitude in local soils. Shannon diversity index of fungal community decreased from 2.5 to 1.2 along the latitudinal gradient in transplanted soils while local soils increased from 0.9 to 2.4 with latitude. Based on our results, microbial activity is driven mainly by changes of the soil substrate along latitudinal and climatic gradients while microbial biomass is driven more by global climatic factors itself. The diversity of soil microbial communities is mostly affected by latitudinal and climatic factors while community structure is mostly shaped by substrate quality.

Keywords: Soil microbiota; PLFA; microbial biomass C; microbial diversity; climatic gradient; DNA sequencing 


\section{Introduction}

Soil microbiota (bacteria and fungi) play crucial roles in nutrient cycling (Fierer, 2017), the maintenance of soil fertility (Ramirez et al., 2010) and soil carbon sequestration (Trivedi et al., 2013). In addition, soil bacteria and fungi have both direct and indirect effects on the health of plants and animals in terrestrial ecosystems (Bardgett and van der Putten, 2014; Xu et al., 2015). Therefore, it is not surprising that the investigation of factors shaping soil microbial communities has become the Holy Grail in recent microbial ecology (Bardgett and van der Putten, 2014; Fierer, 2017).

Recent progress of instrumental analytical methods such as analysis of phospholipid fatty acids (PLFA) (Oravecz et al., 2004) or advanced molecular methods such as sequencing of environmental DNA (Caporaso et al., 2011) allow us more detailed insight into composition and structure of soil microbiota. For example, content of phospholipid fatty acid provides reliable information about relative abundance of living organisms (Oravecz et al., 2004) while DNA methods provide information about total diversity of soil microbiota at finer taxonomic levels (Caporaso et al., 2011). Synthesis of modern analytical methods such as PLFA or DNA sequencing with standard laboratory techniques, for example basal soil respiration or microbial biomass $\mathrm{C}$ provide us detailed view on functioning and diversity of soil microbial communities.

Recognized major drivers of microbial communities are temperature (Zhou et al., 2016), precipitation (de Vries et al., 2013; Evans and Wallenstein, 2014) and also various characteristics of the soil substrate (Birkhofer et al., 2012; Häkkinen et al., 2010; Rousk et al., 2010; Selonen and Setälä, 2015). For example, Lauber et al. (2009) showed pH as a main predictor of the relative abundance of soil bacterial communities across various biomes. In contrast, study of Zhou et al. (2016) showed temperature as a main driver of microbial diversity in soil ecosystem at larger geographical scale. In addition, study of Fierer, (2017) indicate soil 
organic carbon as a key factor shaping diversity and structure of soil microbial communities worldwide.

Although the effect of soil physical and chemical soil properties shaping soil microbial communities at local scales is well known, it is often unclear how the composition and activity of microbial communities correlate with these key ecological factors ( $\mathrm{pH}$, moisture, temperature) along latitudinal gradient. The traditional concept in microbial ecology postulates that "everything is everywhere, but the environment selects" (Barberán et al., 2014a; de Wit and Bouvier, 2006). This principle is a useful basis for the study of biogeography and the structures of natural communities (Dequiedt et al., 2011).

Recent findings suggest that the composition and structure of microbial communities are shaped by factors related to operating at large scales, such as climate (Delgado-Baquerizo et al., 2017; Dequiedt et al., 2011) and/or to local edaphic characteristics such as soil pH (Birkhofer et al., 2012; Rousk et al., 2010, 2009) or litter quality (Prober et al., 2015; Wardle et al., 2004). However, datasets comparing effect of local (e.g. soil pH) and global factors (e.g. temperature, precipitation) affecting soil microbiota along large geographical gradients as well as effect of these factors on metabolic activity of soil microbiota (e.g. basal soil respiration) remains underestimated (Lazzaro et al., 2011; Rui et al., 2015; Sun et al., 2014; Vanhala et al., 2011).

To address this question, we established field transplantation experiment to explore the role of local soil condition $(\mathrm{pH})$ and global factors (precipitation, temperature) on the biomass (microbial biomass C), structure (based on DNA and PLFA) and activity (basal soil respiration) of soil microbial communities. We transplanted sterilized soil from Central Europe (Czech Republic) along a latitudinal gradient in Europe (Finland, United Kingdom, Czech Republic and Greece) and North America (Illinois, USA). We hypothesize that if soil microbiota in 
transplanted soil is more similar to the local soils at donor site, then local soil factors are the primary determinants of microbial communities; by contrast, if the transplanted soil is more similar to the local soil at receptor site, then large-scale drivers (temperature, precipitation) are the most important.

\section{Material and methods}

\subsection{Sampling sites}

The soil used in this experiment was obtained from the forefield of an open-cast mine Jiři near the town of Sokolov in the Czech Republic. The entire area of the Jiři mine forefield was formerly part of an agricultural landscape. This agricultural landscape was abandoned 30-40 years ago. At present, this area is covered by a mixture of grasslands and open woodlands dominated by birch (Betula pendula) and aspen (Populus tremula) on loamy cambisol soils (Holec and Frouz, 2005; Lukešová, 1993). The soil was sampled from grassland accompanied by $P$. tremula and B. pendula in April 2008 using a soil corer ( $6 \mathrm{~cm}$ in diameter). Soil was taken to the depth of $10 \mathrm{~cm}$ after the removal of vegetation from 10 sampling sites. Samples were pooled into one composite sample weighing about $20 \mathrm{~kg}$. The soil was sieved through a $2 \mathrm{~mm}$ mesh to remove roots, branches and other visible plant remains and soil animals. The soil was homogenized and packed in $0.5 \mathrm{~kg}$ portions in Ziploc bags and then sterilized with a $40-\mathrm{kGy}$ dose of gamma radiation (Frouz et al., 2016). The efficiency of the sterilization was tested by inoculating of soil suspension on Malt extract agar media, where no microbes were present after incubation (Frouz et al., 2016).

\subsection{Experimental design}

The sterilized soil was then transported in sealed bags to six receptor sites (including the original donor site) located on a south-north gradient across Europe and in the USA (Table 1). Selection of plant community for our study was critical. In most of the receptor sites considered 
in our study semi-natural forest and grasslands form most of the landscape (Häkkinen et al., 2010). There is known that these two types of habitat differ in microbial community biomass composition and activity (Fierer et al., 2012; Lauber et al., 2009). For that reasons we choose in each acceptor site habitat that was mixture of grassland and trees or woody vegetation. At the receptor sites, the soil was placed into sterilized plastic pots $(12 \mathrm{~cm}$ in diameter; $10 \mathrm{~cm}$ high) during the last week of May and early June 2008. The pots were placed into the soil so that the rim of the pots was about $3 \mathrm{~cm}$ above the soil surface to prevent the soil in the pots being affected by the vegetation cover. Vegetation cover at each receptor sites has been removed under the pot and in $5 \mathrm{~cm}$ around. Nine pots were placed at each receptor site as well as at the donor site. The pots were perforated at the bottom to allow water exchange. Three locations were used at each site. The distance between the pots at one location was approximately 1 meter. A brief description of all the sites is summarized in Table 1. After one year of exposure (June 2009), all the pots from all receptor and donor sites were collected and the soil in the pots was gently placed into Ziplock bags. At the same time, local soil was collected from soil surface layer $0-10 \mathrm{~cm}$ about $1 \mathrm{~m}$ from the pots as a control. Several pots at sampling locations in the Czech Republic, USA and Greece were damaged by fire and wild boars, so only undestroyed pots were taken. The samples were kept at a temperature similar to that at their sampling sites and shipped back to the laboratory for soil analysis. The local soil samples were sieved through a $2 \mathrm{~mm}$ mesh to remove roots, branches and other visible plant remains and soil animals. All laboratory analyses of soil properties were done within one week after sample collection. Transplanted soil samples at various receptor sites did not show any significant differences in soil $\mathrm{pH}$ and texture after one year of exposure. Soil samples for basal soil respiration and microbial biomass $\mathrm{C}$ were stored at $4{ }^{\circ} \mathrm{C}$ and soil samples for PLFA and DNA extraction were freeze dried and stored in a freezer at $-80{ }^{\circ} \mathrm{C}$.

\subsection{Measurement of basal soil respiration and microbial biomass $C$}


Basal soil respiration was measured using the traditional incubation method. Soil (10 g) was enclosed in airtight bottles. Each bottle was equipped with a small container with $\mathrm{NaOH}$ and incubated at $20^{\circ} \mathrm{C}$ for one week. Carbon dioxide $\left(\mathrm{CO}_{2}\right)$ released from the soil was trapped in 3 $\mathrm{ml}$ of $0.5 \mathrm{M} \mathrm{NaOH}$ and then quantified by titration with $0.5 \mathrm{M} \mathrm{HCl}$ after addition of $\mathrm{BaCl}_{2}$ (Jenkinson and Powlson, 1976). The amount of $\mathrm{CO}_{2}$ was expressed as $m g \mathrm{CO}_{2}-\mathrm{C} \mathrm{kg}^{-1} \mathrm{~h}^{-1}$. The same bottles without soil were used to assess $\mathrm{CO}_{2}$ trapping during incubation (from air closed in vials) and during handling. The microbial biomass $\mathrm{C}$ was determined by the chloroform fumigation-extraction method (Vance et al., 1987). Fumigated and non-fumigated soil samples ( $5 \mathrm{~g}$ ) were shaken in glass bottles with $0.5 \mathrm{M} \mathrm{K}_{2} \mathrm{SO}_{4}$ solution $(40 \mathrm{ml})$ for $45 \mathrm{~min}$ and then $\mathrm{C}$ content in the filtrates was determined by dichromate digestion. The microbial biomass $\mathrm{C}$ was obtained by subtraction of fumigated and non-fumigated samples multiplied by extraction coefficient. The microbial biomass $\mathrm{C}$ was expressed as $\mathrm{mg} \mathrm{kg}^{-1}$ soil.

\subsection{Extraction and analysis of phospholipid fatty acid (PLFA)}

Phospholipid fatty acid (PLFA) analysis were extracted by a chloroform-methanol-phosphate buffer from one gram of freeze-dried soil. LiChrolut Si-60 solid-phase extraction cartridges (Merck, Whitehouse Station, NJ) were used to separate the phospholipid fraction (Oravecz et al., 2004) from liquid sample. Phospholipid fractions were subjected to mild alkaline methanolysis (Frostegard et al., 2011; Oravecz et al., 2004). Gas chromatography-mass spectrometry (GC-MS) was used for the analysis of free methyl esters of phospholipid fatty acids (450-GC, 240-MS ion trap detector, Varian, Walnut Creek, CA, USA). The GC instrument was equipped with a split/splitless injector and a DB-5MS column (J\&W Scientific, Folstom, CA, $60 \mathrm{~m}, 0.25 \mathrm{~mm}$ i.d., $0.25 \mu \mathrm{m}$ film thickness) was used for separation.

The temperature program started at $60{ }^{\circ} \mathrm{C}$ and was held for $1 \mathrm{~min}$ in splitless mode. Then the splitter was opened and the oven heated to $160{ }^{\circ} \mathrm{C}$ at a rate of $25^{\circ} \mathrm{C} \mathrm{min}{ }^{-1}$. The second temperature ramp was up to $280{ }^{\circ} \mathrm{C}$ at a rate of $2.5^{\circ} \mathrm{C} \mathrm{min}^{-1}$, this temperature being maintained 
for $10 \mathrm{~min}$. The solvent delay time was set to $8 \mathrm{~min}$. The transfer line temperature was set to $280^{\circ} \mathrm{C}$. Mass spectra were recorded under electron impact at $70 \mathrm{eV}$, mass range 50-350 amu. Methylated fatty acids were identified according to their mass spectra and quantified using their individual chemical standards obtained from Sigma-Aldrich, Prague, Czech Republic and Matreya LLC, Pleasant Gap, PA, USA. Fungi (eukaryotic) were quantified based on 18:2 $\omega 6,9$ content while bacteria were quantified as the sum of i14:0, i15:0, a15:0, i16:0, 16:167,

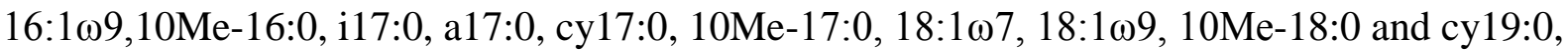
(Šnajdr et al., 2008).

\subsection{DNA extraction and 454 sequencing analysis}

Genomic DNA was extracted from soil samples using the Fast DNA Spin kit for soil DNA extraction (MP Biolabs, Solon, OH, USA) according to the manufacturer's instruction and then amplified by the PCR method (Větrovský and Baldrian, 2013). To amplify the V4-V5 hypervariable regions of the $16 \mathrm{~S}$ rRNA and ITS1, ITS4 regions of 18S rRNA genes for pyrosequencing, universal bacterial primers 519F (50-CAGCMGCCGCGGTAATWC-30) and 926R (50 CCGTCAATTCMTTTRAGTT-30) (Caporaso et al., 2011) and fungal ITS1 and ITS4 (Větrovský and Baldrian, 2013) were used in the PCR. The first amplification step used bacterial 519F and 926R as well as fungal ITS1 and ITS4 specific primers to amplify the bacterial 16S rRNA gene and the internal transcribed spacer (ITS) region of the fungal 18S rRNA gene. Each DNA sample was purified using the Wizard SV Gel and PCR Clean-Up System (Promega, Madison, WI, USA). The purified DNA concentration was determined using ND1000 (NanoDrop, Wilmington, DE, USA).

In the second amplification step, fusion primers were arranged for tag-encoded 454Titanium pyrosequencing: Different barcode sequences were added to the 50 end of the forward primer separated by a trinucleotide spacer. The Titanium A adaptor was also used (Roche, Basel, Switzerland). The PCR products were purified using the MinElute PCR Purification Kit 
(Qiagen, Hilden, Germany) and quantified using a NanoDrop 1000 device (NanoDrop) and the Quant-iT Picogreen dsDNA Assay Kit (Invitrogen, Carlsbad, CA, USA). Purified amplicons were used for the subsequent emulsion PCR (emPCR Kit Lib-L, Roche, Basel, Switzerland), the products of which were sequenced on a GS Junior platform (Roche) in accordance with the manufacturer's instructions.

Bacterial and fungal sequences were processed with the QIIME 1.6.0 software package (Caporaso et al., 2010). Quality filtering steps were performed to trim off barcodes and primers from the raw sequences and to remove sequences that were less than $200 \mathrm{nt}$ long, had homopolymers longer than $6 \mathrm{nt}$, and that had a quality score greater than $20 \mathrm{nt}$. Denoising was performed as described by Reeder et Knight (2010). QIIME's implementation of the OTU pipeline script (Edgar et al., 2011) was applied for chimera checking and OTU picking. Microbial BLAST databases of bacterial 16S rRNA as well as the ITS1 and ITS4 regions were used as reference databases for the detection of bacterial and fungal chimeric sequences. Resulting chimera-free reads were clustered into OTUs based on their sequence similarity at 97\%. Representative sequences of each OTU were aligned using MUSCLE (Edgar, 2004) and used to assign OTUs to taxonomic groups. The BLAST database was used to taxonomically classify the bacterial and fungal sequences. Raw sequences of the bacterial $16 \mathrm{~S} r$ RNA gene as well as the ITS1 and ITS4 regions of the 18S rRNA gene are stored in the European Nucleotide archive (http://www.ebi.ac.uk/ena/data/view/PRJEB23248).

\subsection{Statistical analysis}

Residues were checked by Shapiro-Wilk test and Komolgorov-Smirnov test respectively. Residues full-filed the assumptions of normality and homoscedasticity for multiple comparison tests. Filtering of the raw OTU table, the OTU richness, Shannon index (based on number of OTUs), relative abundances of bacterial and fungal taxa as well as permuted MANOVA analysis were performed using the 'Phyloseq' packages (McMurdie and Holmes, 2013, 2012). 
Linear regression was used to show significant effect of latitudinal gradient on basal soil respiration, microbial biomass $\mathrm{C}$, content of bacterial and fungal PLFA and microbial diversity (based on DNA sequencing). Principal coordinates analysis (PCoA) of weighted UniFrac distance were used to evaluate the overall structural change of soil prokaryotic communities and was performed using the 'Phyloseq' R package (Lozupone and Knight, 2005; McMurdie and Holmes, 2013, 2012). The effect of environmental factors on relative abundance of bacterial and fungal phyla were tested by two-way ANOVA followed by Tukey-Kramer Multiple Comparison Test using basic statistics in $\mathrm{R}$ package. Regression tree analyses were conducted using the 'rpart' $\mathrm{R}$ package (CP value set at 0.01 ) to determine which environmental factors explained the deviance of bacterial and fungal biomass (Breiman, 1984).

\section{Results}

\subsection{Basal soil respiration and microbial biomass $C$}

Linear regression model showed significantly higher basal soil respiration for local soils in comparison with transplanted soils (Fig. 1A). Additionally, basal soil respiration in local soils significantly increased 22 to $42 \mathrm{mg} \mathrm{CO}_{2}-\mathrm{C} \mathrm{kg}^{-1} \mathrm{~h}^{-1}$ with latitude while basal soil respiration in transplanted soils decreased from 32 to $19 \mathrm{mg} \mathrm{CO}_{2}-\mathrm{C} \mathrm{kg}^{-1} \mathrm{~h}^{-1}$ significantly with latitude (Fig. 1A). In contrast, no statistically significant differences in microbial biomass $\mathrm{C}$ were detected between local and transplanted soils. The microbial biomass $\mathrm{C}$ in transplanted soils as well as in local soils significantly decreased with latitude (Fig. 1B).

\subsection{Fungal and bacterial PLFA}

Fungal PLFA showed higher overall content than bacterial PLFA. Linear regression model showed significant differences in content of both fungal and bacterial PLFA between transplanted and local soils along the latitudinal gradient. Fungal PLFA content in local soils significantly increased along the latitudinal gradient while transplanted soils did not show any 
significant changes along the latitudinal gradient (Fig. 1C). As with fungal PLFA, bacterial PLFA content in local soils increased significantly along the latitudinal gradient (Fig. 1D). In contrast, bacterial PLFA content in transplanted soils showed marginal variation with the latitudinal gradient. Bacterial and fungal PLFA content in local soils was significantly higher than in transplanted soils (Fig. 1C, D). To identify the most influential climatic (temperature, precipitation, latitude) and soil factors $(\mathrm{pH})$ among various site locations, correlations between environmental factors (data shown in Table 1) and the fungal and bacterial PLFA content were determined using regression tree analysis (Fig. 2A, B). The regression tree analysis unveiled precipitation as most influential environmental factors determining bacterial community, while fungal community was mostly affected by latitude (Fig. 2A, B).

\subsection{Diversity, structure and composition of microbial community}

In total, we identified 2918 bacterial and 707 fungal OTUs (with 97\% accuracy) whose relative frequency exceeded $0.01 \%$. Shannon diversity index of fungal community decreased significantly from 2.5 to 1.2 along the latitudinal gradient in transplanted soils while local soils increased from 0.9 to 2.4 with latitude (Fig 1E). In contrast, Shannon index of bacterial community did not show any significant pattern between local and transplanted soils along the latitudinal gradient (Fig 1F).

Permuted multivariate analysis of variance showed significant changes in the structure of soil bacterial and fungal communities based on a weighted UniFrac distance matrix across various receptor sites. Principal coordinates analysis (PCoA) showed clear changes in the structure of both bacterial and fungal communities at the various receptor sites (Fig 3A, B). Furthermore, the resulting PCoA diagram (Fig 3A, B) well illustrates significant changes in bacterial community structure between local and transplanted soils. By contrast, our results do 
not indicate any overall differences in fungal community structure between local soils and transplanted soils.

We identified five fungal phyla in both local and transplanted soils from different sites along various latitudes (Fig. 4A). Two-way ANOVA showed significant changes in relative abundances of Ascomycota, Basidiomycota and Glomeromycota at various receptor sites $(\mathrm{F}=4.45 ; \mathrm{p}<0.001 ; \mathrm{df}=5)$ as well as between local and transplanted soils $(\mathrm{F}=5.6 ; \mathrm{p}<0.001 ; \mathrm{df}=1)$. Other phyla did not show any significant differences between receptor sites as well as between local and transplanted soils. Transplanted soils showed higher relative abundance of phylum Ascomycota, Basidiomycota and Glomeromycota than those from local soils. By contrast, five bacterial phyla differed significantly in soils taken from various donor and receptor sites (Fig 4B). Soils transplanted to Finland exhibited greater relative abundances of Acidobacteria, Actinobacteria, Bacteroidetes, Gemmatimonadetes and Proteobacteria. Proteobacteria had the highest relative abundance in transplanted soil.

\section{Discussion}

The increase in microbial respiration observed in local soils but not in transplanted soils suggests that soil respiration is driven more by local soil conditions. We hypothesize that increase in local soils may be mainly due to the amount and quality of soil organic matter, which may, however, be indirectly affected by climatic factors (Delgado-Baquerizo et al., 2017; García-Palacios et al., 2013; Prober et al., 2015). This effect may correspond with well-known latitudinal changes in plant traits with changing climatic conditions and consequently with changes in litter quality (García-Palacios et al., 2013; McGill et al., 2006; Reich and Oleksyn, 2004). In contrast, decreasing of basal soil respiration in transplanted soils may correspond with climatic factors such as temperature and precipitation which in turn affecting metabolic activity of soil microbial communities (Zhou et al., 2016). 
In contrast to microbial respiration, microbial biomass $\mathrm{C}$ did not show any significant changes between local and transplanted soils. This fact indicates that the effect of global climatic factors is more pronounced in this case than the effect of local soil conditions. We found decreasing microbial biomass $\mathrm{C}$ in soils from various sites along the latitudinal gradient. Here we should underline that microbial biomass $\mathrm{C}$ includes the biomass of all microscopic organisms in the soil, not only of bacteria and fungi, but also of protozoans and microscopic metazoans (Schmitt and Glaser, 2011). We hypothesize, carbon resides in the vegetation and soil at lower latitudes for a shorter time than at higher latitude due interaction of metabolic activity of soil microbes with temperature (Carvalhais et al., 2014; Zhou et al., 2016).

The increase in relative abundance of bacteria and fungi (based on PLFA content) along latitudinal gradient as well as microbial respiration observed in local soils but not in transplanted soils suggests that these characteristics of the soil microbiota are driven more by local soil conditions than global factors, which may, however, be affected indirectly by the effect of climatic factors on soil chemistry (Birkhofer et al., 2012; García-Palacios et al., 2013). Also, our regression tree analysis singled out precipitation as the main factor controlling content of bacterial PLFAs. Fungal PLFAs content was mostly affected by latitudinal changes, which partly corroborates the study of Tedersoo et al. (2014), which identified latitude as the main factor controlling fungal communities.

The observed increases in relative abundance of bacteria and fungi (PLFA) with increasing latitude are probably influenced by increased total carbon in soil (Wang et al., 2012). These results correspond to other similar studies done worldwide (Liu et al., 2008; Wang et al., 2012). This finding indicates that global factors, namely climatic factors strongly affect microbial communities directly via precipitation (Yao et al., 2017) and temperature (Zhou et al., 2016) or indirectly via the effect of the climate on the quality of leaf litter, which in turn plays a key role in shaping the soil biota community (Delgado-Baquerizo et al., 2017; Frouz et 
al., 2013; Wardle et al., 2004). One may also argue that after one year, a microbial community is still developing and that it would be interesting to follow its development for a longer period. However, after a longer period, conditions might change in such a way that it would become difficult to tell whether what is followed is the development of the microbial community per se or its response to temporal soil changes, as transplanted soil is likely to increasingly resemble local soil over time.

We found a decreased Shannon index of fungal communities with increasing latitude. This pattern corroborates general patterns described for aboveground communities (Gaston, 2000; Ricklefs, 2004). We expect that interaction of temperature with metabolism shaping all biological processes and having a strong impact on ecological patterns and processes (Okie et al., 2015; Zhou et al., 2016). In our study, however, this was true only for transplanted soils, whereas local soils showed increased diversity of soil fungal community. This may be caused by the fact that communities of transplanted soils were still under development and responding to colonization potential and major environmental drivers. In more mature local soils, their diversity can be more sensitive to heterogeneity of the soil environment, which provides enormous potential for niche partitioning, thus allowing high levels of local biodiversity (DiniAndreote et al., 2014; Fierer, 2017).

We agree with study of Treseder (2014) showing that phylogenetically older phyla prefer lower latitudes with warmer and wetter conditions than younger phyla, which prefer colder and drier climates. This hypothesis may also explain the higher diversity of microbial communities at lower latitudes observed in the current study. We suggest that the dominance and wider occurrence of bacterial communities could be explained by the fact that bacteria are considered phylogenetically older organisms than fungi (Treseder et al., 2014). We agree that exposure time affects the composition and structure of microbial communities. We used soil 
samples deposited at receptor sites for one year. We hypothesize that spatio-temporal changes take place in microbial communities at large temporal scales (Dini-Andreote et al., 2014).

Furthermore, we expect, that fungal communities and, in general, the taxa involved in the fungal decomposition pathway (such as fungal-feeding nematodes) prefer lower temperatures and are more tolerant to higher soil moisture levels (Bhusal et al., 2015). The weighted UniFrac distance between communities - a measure of beta diversity (Lozupone and Knight, 2005) - suggests that sites with similar latitudes are more similar regardless of their actual geographic distance. This is true for both local and transplanted soils in our study. This finding stands in agreement with other similar studies (Fierer et al., 2012; Lauber et al., 2009) that consider edaphic factors (e.g. the parent rock, soil $\mathrm{pH}$, moisture, etc.) as well as aboveground communities as the main drivers of beta diversity. For example, Lauber et al. (2009) showed a disproportion of beta diversity between acidic and alkaline soil across various biomes. By contrast, Prober et al. (2015) showed a positive interaction between the composition of aboveground communities and fungal communities in soils.

Finally, our results have revealed significant variation in alpha as well as beta diversity of soil microbes among various receptor sites. Our results did not show any overall difference between local and transplanted soils when all sites were evaluated together. This is probably a result of high variation among sites, which mask differences between local and transplanted soils. We speculate that variation in microbial diversity results from random events such as the birth, death, immigration and emigration of soil microbes, as has recently been proposed in the literature (Dini-Andreote et al., 2015; Lee et al., 2013; Zhou et al., 2014).

However, we found significant differences between local and transplanted soils at individual receptor sites; for example, in Finland and Greece the transplanted soils significantly differed from the local ones. Similar studies with transplanted soil blocks, such as that of Castro 
et al. (2010), report changes in the relative abundances and composition of fungal communities to be shaped by the precipitation regime and temperature. Study of Rui et al. (2015) showed that transplanted soil bacterial communities became more similar to those at their receptor sites and more different from those at their donor sites. However, that study considered soil transplantation along an elevation gradient at a regional scale and considered bacterial communities only.

Our results do not indicate any clear pattern of bacterial diversity at various donor and receptor sites. In agreement with recent studies (Barberán et al., 2014b), we suggest that bacteria are ubiquitous across the diversity of habitats. In addition, our results indicate that Proteobacteria have the highest relative abundance in transplanted soils. We hypothesize that Proteobacteria dominate in transplanted sterile soil because the group is made up of fastgrowing taxa (Fierer et al., 2007). We suggest that fast growing bacteria indicate increased growth in habitats with a higher amount of available nutrients such as sterilized soils containing dead cells and dead organic matter. Similar pattern was shown also for soil fungal community showing increased relative abundance of Ascomycetes, Basidiomycetes and Glomeromycota in transplanted soils. This indicate that sterilized soils promotes better conditions for fungal growth via released nutrient and available niches. Additionally, we found higher relative abundance of soil fungi in boreal soils (Finland), showing that forest soils promote good conditions for fungal growth as was shown in previous studies (e. g. Vorř́šková et al., 2011).

\section{Conclusion}

An increase in basal soil respiration in local but not in transplanted soils suggests that microbial activity is driven mainly by changes of the soil substrate along latitudinal and climatic gradients. The decreasing values of the microbial biomass $\mathrm{C}$ with latitude suggests that this parameter is driven by global climatic factors. Differences between microbial biomass C and PLFA may be 
explained by increases in deposited nutrients in cells, resulting in a larger body size of microbes at sites situated at higher latitudes. The observed increase in bacterial and fungal PLFA seems to be driven by latitudinal changes in substrate quality. The alpha diversity of soil fungal communities is mostly affected by latitudinal and climatic factors whereas their beta diversity (community structure) is mostly shaped by substrate quality.

\section{Acknowledgements}

This research was supported by the Czech Academy of Sciences, grant No. L200961602.

Furthermore, this work was supported by the Ministry of Education, Youth and Sports of the

Czech Republic (projects COST-CZ LD13046, LM2015075, EF16_013/0001782), University

Research Centre of Charles University in Prague (UNCE 204016) and project LC06066.

\section{References}

Barberán, A., Casamayor, E.O., Fierer, N., 2014a. The microbial contribution to macroecology. Front. Microbiol. 5, 203. doi:10.3389/fmicb.2014.00203

Barberán, A., Ramirez, K.S., Leff, J.W., Bradford, M. a, Wall, D.H., Fierer, N., 2014b. Why are some microbes more ubiquitous than others? Predicting the habitat breadth of soil bacteria. Ecol. Lett. 17, 794-802. doi:10.1111/ele.12282

Bardgett, R.D., van der Putten, W.H., 2014. Belowground biodiversity and ecosystem functioning. Nature 515, 505-511. doi:10.1038/nature13855

Bhusal, D.R., Tsiafouli, M.A., Sgardelis, S.P., 2015. Temperature-based bioclimatic parameters can predict nematode metabolic footprints. Oecologia 179, 187-199. doi:10.1007/s00442-015-3316-4

Birkhofer, K., Schöning, I., Alt, F., Herold, N., Klarner, B., Maraun, M., Marhan, S., Oelmann, Y., Wubet, T., Yurkov, A., Begerow, D., Berner, D., Buscot, F., Daniel, R., Diekötter, T., Ehnes, R.B., Erdmann, G., Fischer, C., Foesel, B., Groh, J., Gutknecht, J., Kandeler, E., Lang, C., Lohaus, G., Meyer, A., Nacke, H., Näther, A., Overmann, J., Polle, A., Pollierer, M.M., Scheu, S., Schloter, M., Schulze, E.D., Schulze, W., Weinert, J., Weisser, W.W., Wolters, V., Schrumpf, M., 2012. General relationships between abiotic soil properties and soil biota across spatial scales and different land-use types. PLoS One 7. doi:10.1371/journal.pone.0043292

Breiman, L., 1984. Classification and regression trees. Chapman \& Hall/CRC.

Caporaso, J.G., Kuczynski, J., Stombaugh, J., Bittinger, K., Bushman, F.D., Costello, E.K., Fierer, N., Peña, A.G., Goodrich, J.K., Gordon, J.I., Huttley, G. a, Kelley, S.T., Knights, D., Koenig, J.E., Ley, R.E., Lozupone, C. a, Mcdonald, D., Muegge, B.D., Pirrung, M., Reeder, J., Sevinsky, J.R., Turnbaugh, P.J., Walters, W. a, Widmann, J., Yatsunenko, T., Zaneveld, J., Knight, R., 2010. QIIME allows analysis of high- throughput community sequencing data. Nat. Publ. Gr. 7, 335-336. doi:10.1038/nmeth0510-335

Caporaso, J.G., Lauber, C.L., Walters, W. a, Berg-Lyons, D., Lozupone, C. a, Turnbaugh, P.J., Fierer, N., Knight, R., 2011. Global patterns of 16S rRNA diversity at a depth of millions of sequences per sample. 
Carvalhais, N., Forkel, M., Khomik, M., Bellarby, J., Jung, M., Migliavacca, M., Mu, M., Saatchi, S., Santoro, M., Thurner, M., Weber, U., Ahrens, B., Beer, C., Cescatti, A., Randerson, J.T., Reichstein, M., Mu, M., Saatchi, S., Santoro, M., Thurner, M., Weber, U., Ahrens, B., Beer, C., Cescatti, A., Randerson, J.T., Reichstein, M., Mu, M., Saatchi, S., Santoro, M., Thurner, M., Weber, U., Ahrens, B., Beer, C., Cescatti, A., Randerson, J.T., Reichstein, M., 2014. Global covariation of carbon turnover times with climate in terrestrial ecosystems. Nature 514, 213-217. doi:10.1038/nature13731

de Vries, F.T., Thébault, E., Liiri, M., Birkhofer, K., Tsiafouli, M. a, Bjørnlund, L., Bracht Jørgensen, H., Brady, M.V., Christensen, S., de Ruiter, P.C., d’Hertefeldt, T., Frouz, J., Hedlund, K., Hemerik, L., Hol, W.H.G., Hotes, S., Mortimer, S.R., Setälä, H., Sgardelis, S.P., Utešeny, K., van der Putten, W.H., Wolters, V., Bardgett, R.D., 2013. Soil food web properties explain ecosystem services across European land use systems. Proc. Natl. Acad. Sci. U. S. A. 110, 14296-301. doi:10.1073/pnas.1305198110

de Wit, R., Bouvier, T., 2006. 'Everything is everywhere, but, the environment selects'; what did Baas Becking and Beijerinck really say? Environ. Microbiol. 8, 755-758. doi:10.1111/j.1462-2920.2006.01017.x

Delgado-Baquerizo, M., Bissett, A., Eldridge, D.J., Maestre, F.T., He, J.-Z., Wang, J.-T., Hamonts, K., Liu, Y.R., Singh, B.K., Fierer, N., 2017. Palaeoclimate explains a unique proportion of the global variation in soil bacterial communities. Nat. Ecol. Evol. 1-9. doi:10.1038/s41559-017-0259-7

Dequiedt, S., Saby, N.P.A., Lelievre, M., Jolivet, C., Thioulouse, J., Toutain, B., Arrouays, D., Bispo, A., Lemanceau, P., Ranjard, L., 2011. Biogeographical patterns of soil molecular microbial biomass as influenced by soil characteristics and management. Glob. Ecol. Biogeogr. 20, 641-652. doi:10.1111/j.1466-8238.2010.00628.x

Dini-Andreote, F., de Cassia Pereira e Silva, M., Triado-Margarit, X., Casamayor, E.O., van Elsas, J.D., Salles, J.F., 2014. Dynamics of bacterial community succession in a salt marsh chronosequence: evidences for temporal niche partitioning. ISME J 8, 1989-2001.

Dini-Andreote, F., Stegen, J.C., van Elsas, J.D., Salles, J.F., 2015. Disentangling mechanisms that mediate the balance between stochastic and deterministic processes in microbial succession. Proc. Natl. Acad. Sci. 112, E1326-E1332. doi:10.1073/pnas.1414261112

Edgar, R.C., 2004. MUSCLE: multiple sequence alignment with high accuracy and high throughput. Nucleic Acids Res. 32, 1792-1797. doi:10.1093/nar/gkh340

Edgar, R.C., Haas, B.J., Clemente, J.C., Quince, C., Knight, R., 2011. UCHIME improves sensitivity and speed of chimera detection. Bioinformatics 27, 2194-2200. doi:10.1093/bioinformatics/btr381

Evans, S.E., Wallenstein, M.D., 2014. Climate change alters ecological strategies of soil bacteria. Ecol. Lett. 17, 155-64. doi:10.1111/ele.12206

Fierer, N., 2017. Embracing the unknown: disentangling the complexities of the soil microbiome. Nat. Rev. Microbiol. doi:10.1038/nrmicro.2017.87

Fierer, N., Bradford, M.A., Jackson, R.B., 2007. Toward an ecological classification of soil bacteria. Ecology 88, 1354-1364. doi:10.1890/05-1839

Fierer, N., Leff, J.W., Adams, B.J., Nielsen, U.N., Thomas, S., Lauber, C.L., Owens, S., Gilbert, J.A., Wall, D.H., Caporaso, J.G., 2012. Cross-biome metagenomic analyses of soil microbial communities and their functional attributes 2-7. doi:10.1073/pnas.1215210110//DCSupplemental.www.pnas.org/cgi/doi/10.1073/pnas.1215210110

Frostegard, A., Tunlid, A., Baath, E., 2011. Use and misuse of PLFA measurements in soils. Soil Biol. Biochem. 43, 1621-1625. doi:10.1016/j.soilbio.2010.11.021

Frouz, J., Livečková, M., Albrechtová, J., Chroňáková, A., Cajthaml, T., Pižl, V., Háněl, L., Starý, J., Baldrian, P., Lhotáková, Z., Šimáčková, H., Cepáková, Š., 2013. Is the effect of trees on soil properties mediated by soil fauna? A case study from post-mining sites. For. Ecol. Manage. 309, 87-95. doi:10.1016/j.foreco.2013.02.013 
Frouz, J., Toyota, A., Mudrák, O., Jílková, V., Filipová, A., Cajthaml, T., 2016. Effects of soil substrate quality, microbial diversity and community composition on the plant community during primary succession. Soil Biol. Biochem. 99, 75-84. doi:10.1016/j.soilbio.2016.04.024

García-Palacios, P., Maestre, F.T., Kattge, J., Wall, D.H., 2013. Climate and litter quality differently modulate the effects of soil fauna on litter decomposition across biomes. Ecol. Lett. 16, 1045-53. doi:10.1111/ele.12137

Gaston, K.J., 2000. Global patterns in biodiversity. Nature 405, 220-227. doi:10.1038/35012228

Häkkinen, M., Heikkinen, J., Mäkipää, R., 2010. Tree influence on carbon stock and C:N ratio of soil organic layer in boreal Scots pine forests. Can. J. Soil Sci. 90, 559-566. doi:10.4141/cjss10035

Holec, M., Frouz, J., 2005. Ant (Hymenoptera: Formicidae) communities in reclaimed and unreclaimed brown coal mining spoil dumps in the Czech Republic. Pedobiologia (Jena). 49, 345-357. doi:10.1016/j.pedobi.2005.03.001

Jenkinson, D.S., Powlson, D.S., 1976. The effects of biocidal treatments on metabolism in soil-V: A method for measuring soil biomass. Soil Biol. Biochem. 8, 209-213. doi:http://dx.doi.org/10.1016/00380717(76)90005-5

Lauber, C.L., Hamady, M., Knight, R., Fierer, N., 2009. Pyrosequencing-based assessment of soil pH as a predictor of soil bacterial community structure at the continental scale. Appl. Environ. Microbiol. 75, 5111-5120. doi:10.1128/AEM.00335-09

Lazzaro, A., Gauer, A., Zeyer, J., 2011. Field-scale transplantation experiment to investigate structures of soil bacterial communities at pioneering sites. Appl. Environ. Microbiol. 77, 8241-8248. doi:10.1128/AEM.05778-11

Lee, J.E., Buckley, H.L., Etienne, R.S., Lear, G., 2013. Both species sorting and neutral processes drive assembly of bacterial communities in aquatic microcosms. FEMS Microbiol. Ecol. 86, 288-302. doi:10.1111/1574-6941.12161

Liu, X.-M., Li, Q., Liang, W.-J., Jiang, Y., 2008. Distribution of soil enzyme activities and microbial biomass along a latitudinal gradient in farmlands of Songliao plain, Northeast China. Pedosphere 18, 431-440. doi:10.1016/S1002-0160(08)60034-X

Lozupone, C., Knight, R., 2005. UniFrac: a new phylogenetic method for comparing microbial communities. Appl. Environ. Microbiol. 71, 8228-8235. doi:10.1128/AEM.71.12.8228-8235.2005

Lukešová, A., 1993. Soil algae in four secondary successional stages on abandoned fields. Algol. Stud. 71, 81102.

McGill, B.J., Enquist, B.J., Weiher, E., Westoby, M., 2006. Rebuilding community ecology from functional traits. Trends Ecol. Evol. 21, 178-185. doi:10.1016/j.tree.2006.02.002

McMurdie, P.J., Holmes, S., 2013. Phyloseq: An R package for reproducible interactive analysis and graphics of microbiome census data. PLoS One 8. doi:10.1371/journal.pone.0061217

McMurdie, P.J., Holmes, S., 2012. Phyloseq: a bioconductor package for handling and analysis of highthroughput phylogenetic sequence data. Pac. Symp. Biocomput. 235-46.

Okie, J.G., Horn, D.J. Van, Storch, D., Barrett, J.E., Gooseff, M.N., Kopsova, L., Takacs-vesbach, C.D., 2015. Niche and metabolic principles explain patterns of diversity and distribution: theory and a case study with soil bacterial communities. Proc. R. Soc. London, Ser. B Biol. Sci. 282. doi:10.1098/rspb.2014.2630

Oravecz, O., Elhottova, D., Kristufek, V., Sustr, V., Frouz, J., Triska, J., Marialigeti, K., 2004. Application of ARDRA and PLFA analysis in characterizing the bacterial communities of the food, gut and excrement of saprophagous larvae of Penthetria holosericea (Diptera : Bibionidae): a pilot study. Folia Microbiol. (Praha). 49, 83-93. doi:10.1007/BF02931652

Prober, S.M., Leff, J.W., Bates, S.T., Borer, E.T., Firn, J., Harpole, W.S., Lind, E.M., Seabloom, E.W., Adler, P.B., Bakker, J.D., Cleland, E.E., DeCrappeo, N.M., DeLorenze, E., Hagenah, N., Hautier, Y., Hofmockel, 
K.S., Kirkman, K.P., Knops, J.M.H., La Pierre, K.J., MacDougall, A.S., McCulley, R.L., Mitchell, C.E., Risch, A.C., Schuetz, M., Stevens, C.J., Williams, R.J., Fierer, N., 2015. Plant diversity predicts beta but not alpha diversity of soil microbes across grasslands worldwide. Ecol. Lett. 18, 85-95. doi:10.1111/ele.12381

Ramirez, K.S., Lauber, C.L., Knight, R., Bradford, M.A., Fierer, N., 2010. Consistent effects of nitrogen fertilization on soil bacterial communities in contrasting systems. Ecology 91, 3463-3470. doi:10.1890/100426.1

Reeder, J., Knight, R., 2010. Rapidly denoising pyrosequencing amplicon reads by exploiting rank-abundance distributions. Nat. Methods 7, 668-669. doi:10.1038/nmeth0910-668b

Reich, P.B., Oleksyn, J., 2004. Global patterns of plant leaf N and P in relation to temperature and latitude. Proc. Natl. Acad. Sci. U. S. A. 101, 11001-11006. doi:10.1073/pnas.0403588101

Ricklefs, R.E., 2004. A comprehensive framework for global patterns in biodiversity. Ecol. Lett. 7, 1-15. doi:10.1046/j.1461-0248.2003.00554.x

Rousk, J., Baath, E., Brookes, P.C., Lauber, C.L., Lozupone, C., Caporaso, J.G., Knight, R., Fierer, N., 2010. Soil bacterial and fungal communities across a pH gradient in an arable soil. ISME J. 4, 1340-1351. doi:10.1038/ismej.2010.58

Rousk, J., Brookes, P.C., Bååth, E., 2009. Contrasting Soil pH Effects on Fungal and Bacterial Growth Suggest Functional Redundancy in Carbon Mineralization. Appl. Env. Microbiol.75, 1589-1596. doi:10.1128/AEM.02775-08

Rui, J., Li, J., Wang, S., An, J., Liu, W. tso, Lin, Q., Yang, Y., He, Z., Li, X., 2015. Responses of bacterial communities to simulated climate changes in alpine meadow soil of the Qinghai-Tibet plateau. Appl. Environ. Microbiol. 81, 6070-6077. doi:10.1128/AEM.00557-15

Schmitt, A., Glaser, B., 2011. Organic matter dynamics in a temperate forest soil following enhanced drying. Soil Biol. Biochem. 43, 478-489. doi:10.1016/j.soilbio.2010.09.037

Selonen, S., Setälä, H., 2015. Soil processes and tree growth at shooting ranges in a boreal forest reflect contamination history and lead-induced changes in soil food webs. Sci. Total Environ. 518-519, 320-327. doi:10.1016/j.scitotenv.2015.03.018

Šnajdr, J., Valaskova, V., Merhautova, V., Herinkova, J., Cajthaml, T., Baldrian, P., 2008. Spatial variability of enzyme activities and microbial biomass in the upper layers of Quercus petraea forest soil. Soil Biol. Biochem. 40, 2068-2075. doi:10.1016/j.soilbio.2008.01.015

Sun, B., Wang, F., Jiang, Y., Li, Y., Dong, Z., Li, Z., Zhang, X.X., 2014. A long-term field experiment of soil transplantation demonstrating the role of contemporary geographic separation in shaping soil microbial community structure. Ecol. Evol. 4, 1073-1087. doi:10.1002/ece3.1006

Tedersoo, L., Bahram, M., Polme, S., Koljalg, U., Yorou, N.S., Wijesundera, R., Villarreal Ruiz, L., VascoPalacios, A.M., Thu, P.Q., Suija, A., Smith, M.E., Sharp, C., Saluveer, E., Saitta, A., Rosas, M., Riit, T., Ratkowsky, D., Pritsch, K., Poldmaa, K., Piepenbring, M., Phosri, C., Peterson, M., Parts, K., Paertel, K., Otsing, E., Nouhra, E., Njouonkou, A.L., Nilsson, R.H., Morgado, L.N., Mayor, J., May, T.W., Majuakim, L., Lodge, D.J., Lee, S.S., Larsson, K.-H., Kohout, P., Hosaka, K., Hiiesalu, I., Henkel, T.W., Harend, H., Guo, L., Greslebin, A., Grelet, G., Geml, J., Gates, G., Dunstan, W., Dunk, C., Drenkhan, R., Dearnaley, J., De Kesel, A., Dang, T., Chen, X., Buegger, F., Brearley, F.Q., Bonito, G., Anslan, S., Abell, S., Abarenkov, K., 2014. Global diversity and geography of soil fungi. Science (80-. ). 346, 1078+. doi:10.1126/science. 1256688

Treseder, K.K., Maltz, M.R., Hawkins, B. a, Fierer, N., Stajich, J.E., McGuire, K.L., 2014. Evolutionary histories of soil fungi are reflected in their large-scale biogeography. Ecol. Lett. 1086-1093. doi:10.1111/ele.12311

Trivedi, P., Anderson, I.C., Singh, B.K., 2013. Microbial modulators of soil carbon storage: integrating genomic and metabolic knowledge for global prediction. Trends Microbiol. 21, 641-51. doi:10.1016/j.tim.2013.09.005 
Vance, E.D., Brookes, P.C., Jenkinson, D.S., 1987. An extraction method for measuring soil microbial biomass C. Soil Biol. Biochem. 19, 703-707. doi:http://dx.doi.org/10.1016/0038-0717(87)90052-6

Vanhala, P., Karhu, K., Tuomi, M., Björklöf, K., Fritze, H., Hyvörinen, H., Liski, J., 2011. Transplantation of organic surface horizons of boreal soils into warmer regions alters microbiology but not the temperature sensitivity of decomposition. Glob. Chang. Biol. 17, 538-550. doi:10.1111/j.1365-2486.2009.02154.X

Větrovský, T., Baldrian, P., 2013. Analysis of soil fungal communities by amplicon pyrosequencing: Current approaches to data analysis and the introduction of the pipeline SEED. Biol. Fertil. Soils 49, 1027-1037. doi:10.1007/s00374-013-0801-y

Voříšková, J., Dobiášová, P., Šnajdr, J., Vaněk, D., Cajthaml, T., Šantrǔčková, H., Baldrian, P., 2011. Chemical composition of litter affects the growth and enzyme production by the saprotrophic basidiomycete Hypholoma fasciculare. Fungal Ecol. 4, 417-426. doi:http://dx.doi.org/10.1016/j.funeco.2011.03.005

Wang, J., Song, C., Wang, X., Song, Y., 2012. Changes in labile soil organic carbon fractions in wetland ecosystems along a latitudinal gradient in Northeast China. Catena 96, 83-89. doi:10.1016/j.catena.2012.03.009

Wardle, D.A., Bardgett, R.D., Klironomos, J.N., Setala, H., van der Putten, W.H., Wall, D.H., 2004. Ecological linkages between aboveground and belowground biota. Science (80-. ). 304, 1629-1633. doi:10.1126/science. 1094875

Xu, X., Passey, T., Wei, F., Saville, R., Harrison, R.J., 2015. Amplicon-based metagenomics identified candidate organisms in soils that caused yield decline in strawberry. Hortic. Res. 2. doi:10.1038/hortres.2015.22

Yao, M., Rui, J., Niu, H., Heděnec, P., Li, J., He, Z., Wang, J., Cao, W., Li, X., 2017. The differentiation of soil bacterial communities along a precipitation and temperature gradient in the eastern Inner Mongolia steppe. Catena 152, 47-56. doi:10.1016/j.catena.2017.01.007

Zhou, J., Deng, Y., Shen, L., Wen, C., Yan, Q., Ning, D., Qin, Y., Xue, K., Wu, L., He, Z., Voordeckers, J.W., Nostrand, J.D. Van, Buzzard, V., Michaletz, S.T., Enquist, B.J., Weiser, M.D., Kaspari, M., Waide, R., Yang, Y., Brown, J.H., 2016. Temperature mediates continental-scale diversity of microbes in forest soils. Nat. Commun. 7, 12083. doi:10.1038/ncomms 12083

Zhou, J., Deng, Y., Zhang, P., Xue, K., Liang, Y., Van Nostrand, J.D., Yang, Y., He, Z., Wu, L., Stahl, D. a, Hazen, T.C., Tiedje, J.M., Arkin, A.P., 2014. Stochasticity, succession, and environmental perturbations in a fluidic ecosystem. Proc. Natl. Acad. Sci. U. S. A. 111, E836-45. doi:10.1073/pnas.1324044111 


\section{Figures captions:}

Fig. 1. Basal soil respiration (A), microbial biomass C (B), fungal (C) and bacterial (D) PLFA concentration, Shannon index of soil fungal (E) and bacterial (F) community in local and transplanted soil distributed along latitudinal gradient. Linear regression model.

Fig. 2. Regression tree analysis depicting the main factors for the bacterial (A) and fungal (B) PLFA concentration in local and transplanted soil distributed at different sites along the climatic gradient.

Fig. 3. Principal coordinates analysis of weighted UniFrac distance matrix fungal (A) and bacterial (B) communities in local and transplanted soil distributed at different sites along the climatic gradient. Permuted MANOVA (Fungi): Site $\left(\mathrm{F}_{5,90}=2.236, \mathrm{p}=0.001\right)$, Treatment $\left(\mathrm{F}_{1,54}=1.215, \mathrm{p}=0.172\right), \quad$ Site $*$ Treatment $\quad\left(\mathrm{F}_{11,198}=1.26, \mathrm{p}=0.017\right)$. Permuted MANOVA (Bacteria): Site $\left(\mathrm{F}_{5,90}=1.415, \mathrm{p}=0.047\right)$, Treatment $\left(\mathrm{F}_{1,54}=1.512, \mathrm{p}=0.027\right)$, Site*Treatment $\left(\mathrm{F}_{11,198}=0.817, \mathrm{p}=0.62\right)$.

Fig. 4. Relative abundance of fungal (A) and bacterial (B) phyla in local and transplanted soils distributed across various sites along the climatic gradient. Asterisk indicates a statistical significant difference $(* \mathrm{p}<0.05 ; * * \mathrm{p}<0.01 ; * * * \mathrm{p}<0.001)$. There were no transplanted sites for Sokolov. Bars represent SE. 

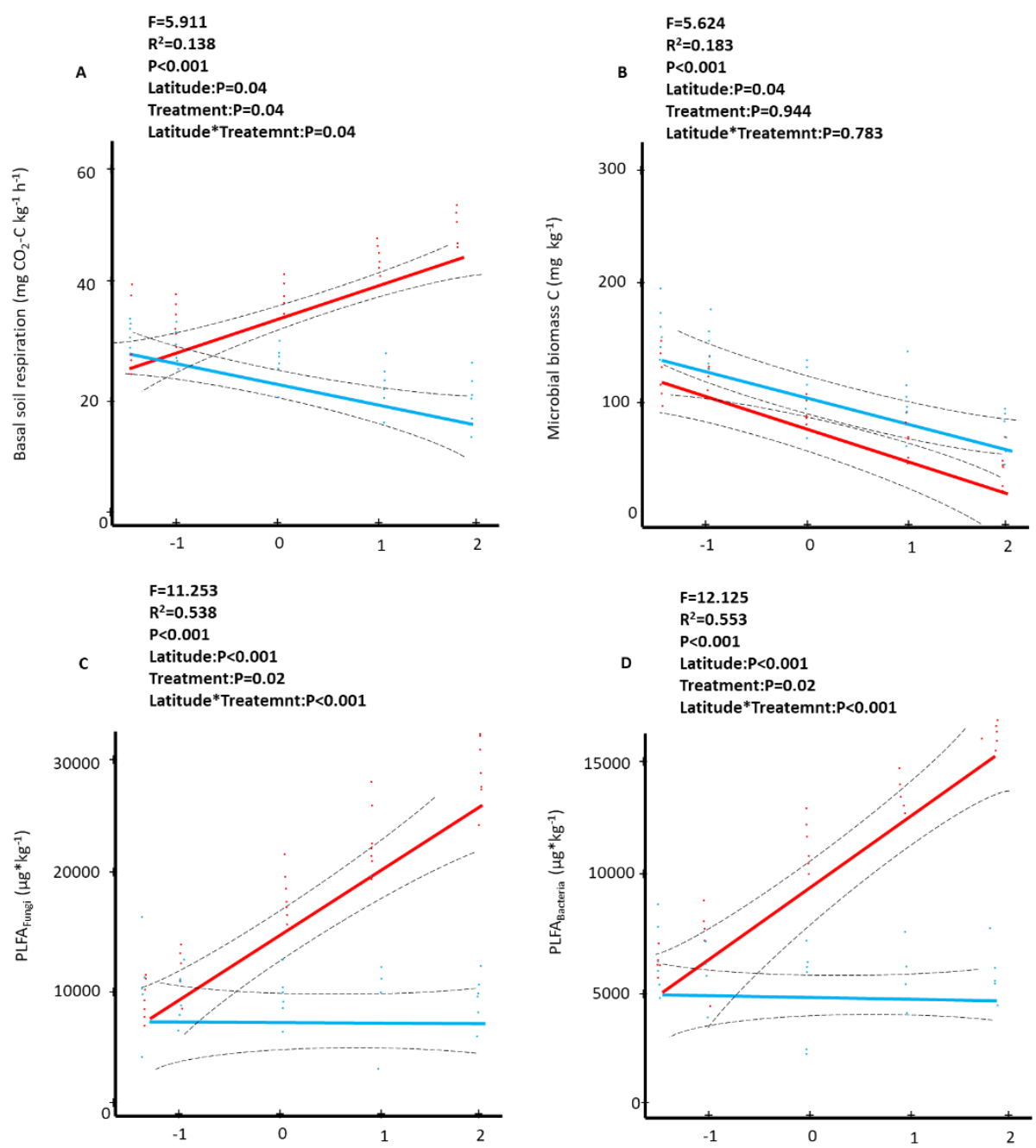

Treatment
- Local

- Transplanted

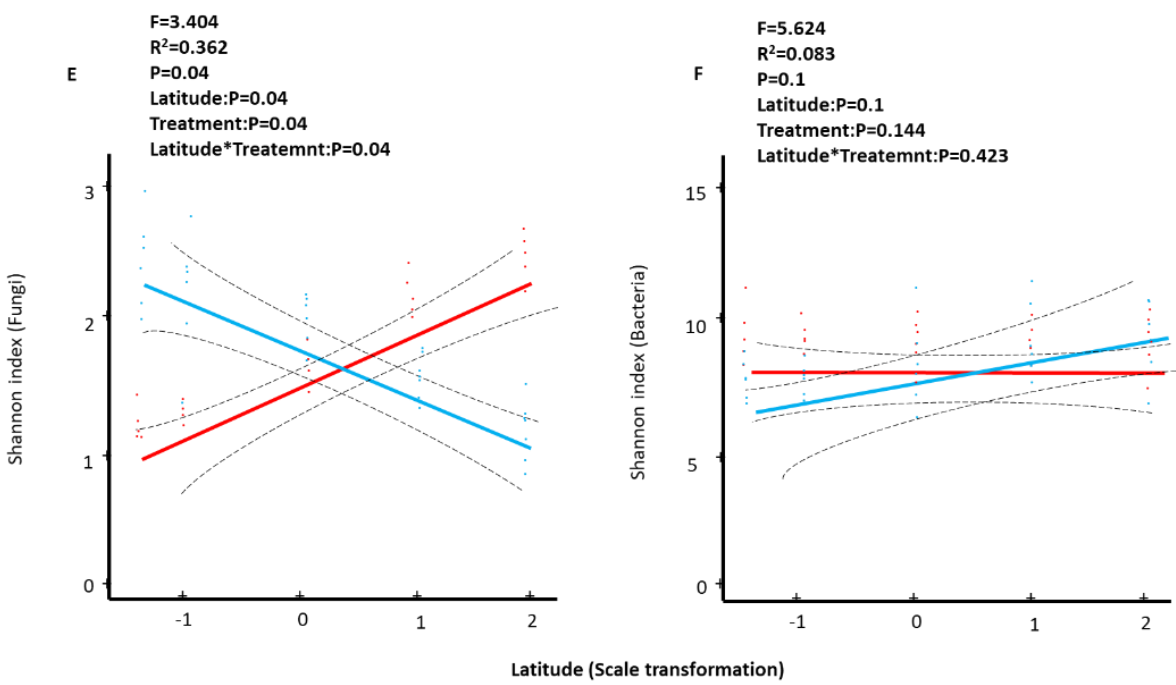

Fig. 1 

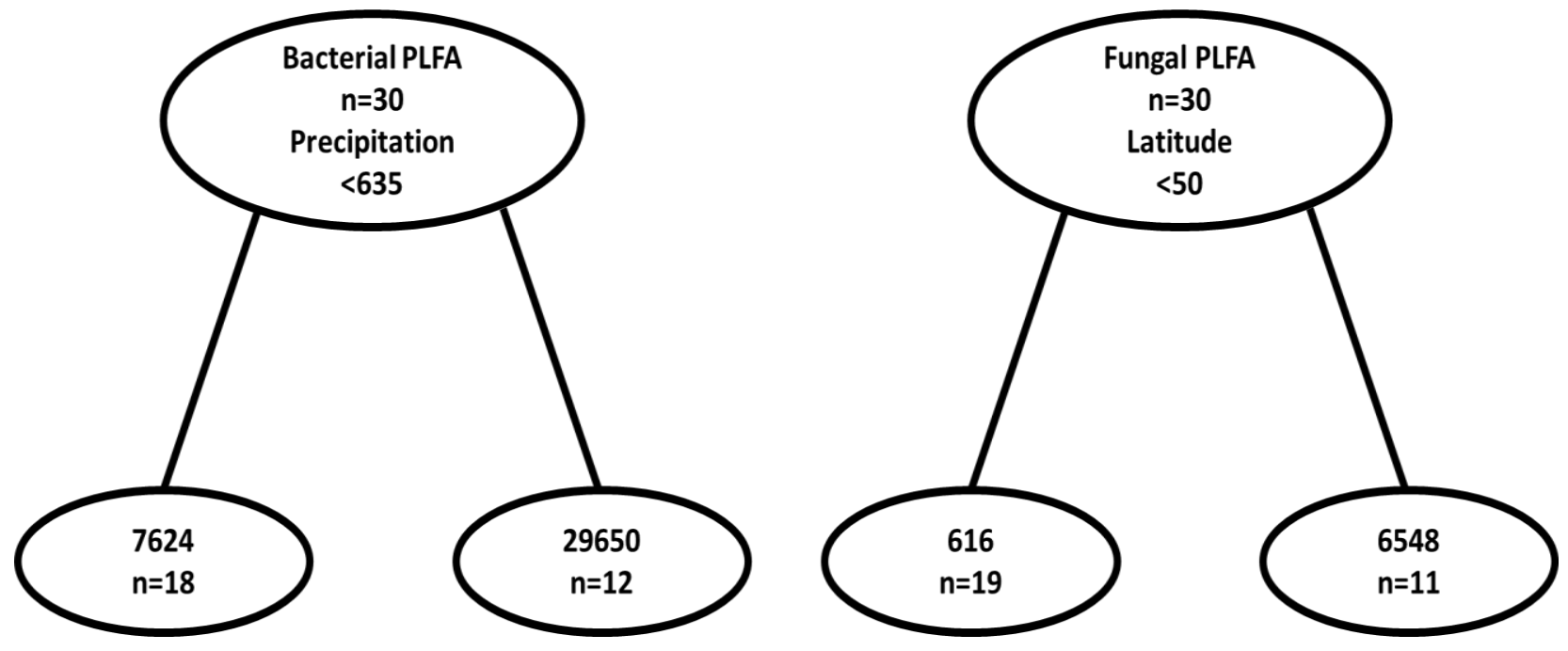

Fig. 2. 
A
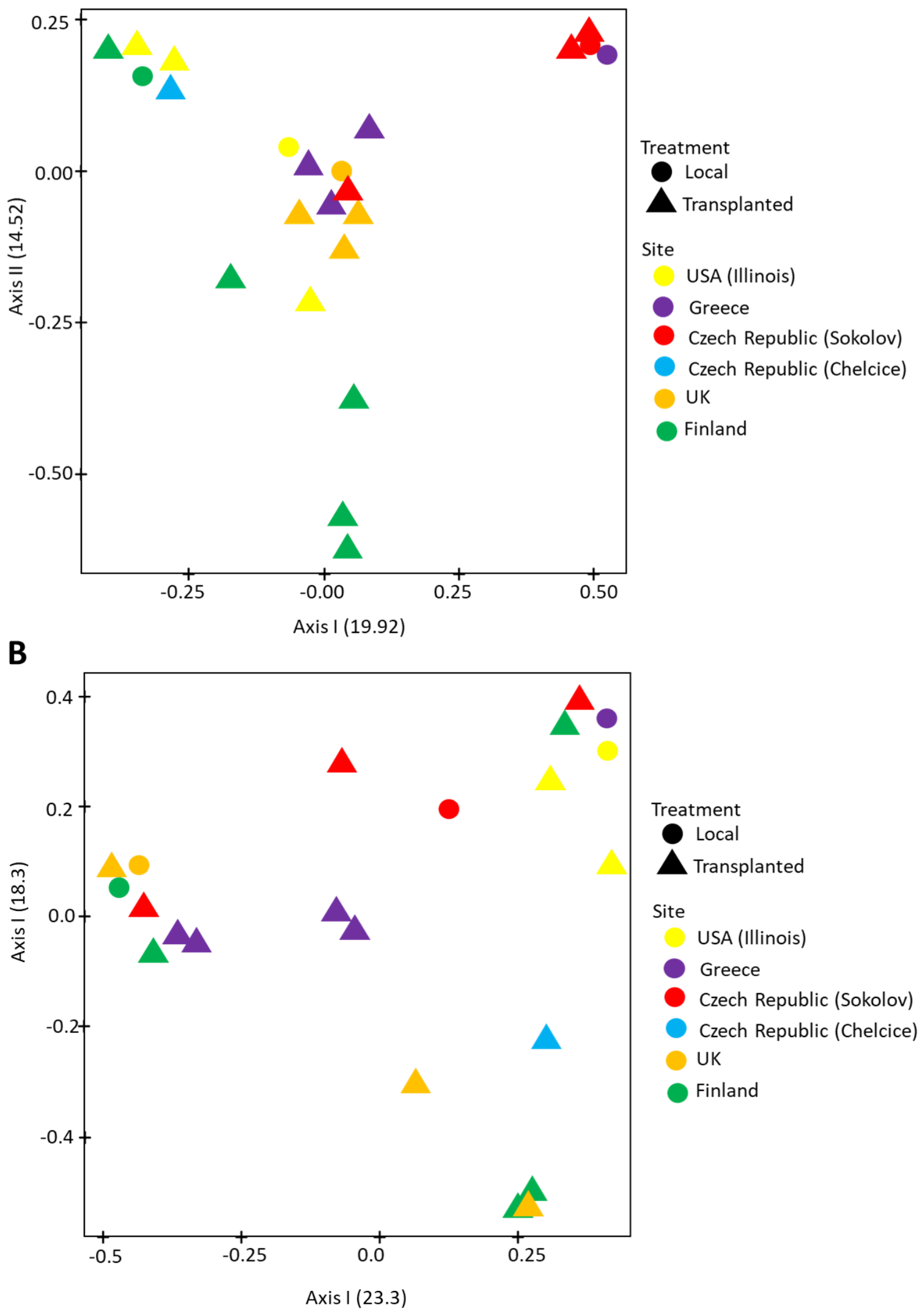

Fig. 3. 


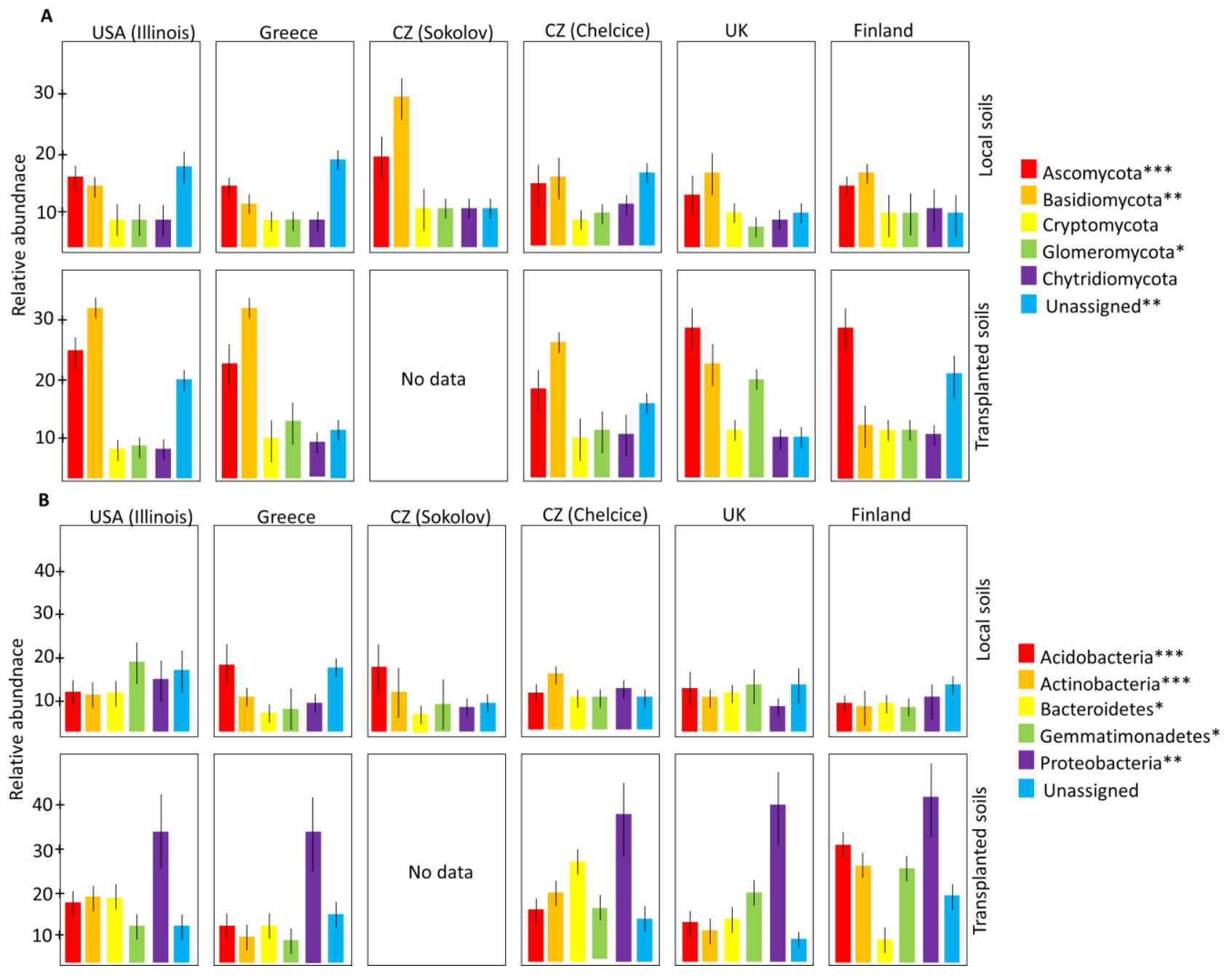

Fig. 4. 
Table 1: Study sites and environmental data for the transplantation experiment. The Sokolov (Czech Republic) site serves as soil donor as well as receptor site; all the other sites were receptors of the soil from Sokolov.

\begin{tabular}{|c|c|c|c|c|c|c|c|c|c|c|}
\hline Country & Latitude & Longitude & Texture & Soil pH & Content of C (\%) & $\mathrm{C}: \mathrm{N}$ ratio & Annual Temperature & Annual precipitation (mm) & Ecosystem type & Reference \\
\hline USA (Illinois) & $38^{\circ} 56^{\prime} 51.7^{\prime \prime} \mathrm{N}$ & $87^{\circ} 13^{\prime} 04.4^{\prime \prime} \mathrm{W}$ & Silty Loam & 6.5 & 2.2 & 13.7 & 13 & 1035 & Open deciduous forest & (Frouz et al., 2013) \\
\hline Greece & $40^{\circ} 43^{\prime} 48.8^{\prime \prime} \mathrm{N}$ & $22^{\circ} 57^{\prime} 02.5 \mathrm{E} \mathrm{E}$ & Loam & 8.6 & 3.7 & 17.6 & 15.9 & 455 & Pasture with trees & (Bhusal et al., 2015) \\
\hline Czech Republic & $50^{\circ} 12^{\prime} 10.54^{\prime \prime} \mathrm{N}$ & $12^{\circ} 38^{\prime} 13.25^{\prime \prime} \mathrm{E}$ & Loam & 6.5 & 5 & 11.9 & 7.5 & 579 & Grassland with trees & (Holec and Frouz, 2005) \\
\hline Czech Republic & $50^{\circ} 12^{\prime} 14.8^{\prime \prime} \mathrm{N}$ & $12^{\circ} 38^{\prime} 13.8^{\prime \prime} \mathrm{E}$ & Loam & 5.3 & 2.2 & 9.16 & 7.3 & 605 & Grassland with trees & (Lukešová, 1993) \\
\hline UK & $51^{\circ} 38^{\prime} 37.2^{\prime \prime} \mathrm{N}$ & $0^{\circ} 38^{\prime} 43.8^{\prime \prime} \mathrm{W}$ & Loam & 7.22 & 3.7 & 9.4 & 11.1 & 621 & Pasture with trees & (de Vries et al., 2013) \\
\hline Finland & $60^{\circ} 59^{\prime} 04.0^{\prime \prime} \mathrm{N}$ & $25^{\circ} 38^{\prime} 38.9^{\prime \prime} \mathrm{E}$ & Loamy sand & 4.5 & 25.4 & 25.6 & 3.9 & 647 & Open spruce forest & (Häkkinen et al., 2010; Selonen and Setälä, 2015) \\
\hline
\end{tabular}

